\title{
The Role of Teamwork, Work Environment, Compensation System in an Effort to Increase Employee Extrinsic Motivation at the Dompet Dhuafa Integrated Health Hospital
}

\author{
Anisah Sri Astuti, Hasyim, and Nofierni
}

\section{ABSTRACT}

The work motivation of employee which have increased it has a positive impact and is very important for the company, by increasing employee motivation will encourage each of them to work hard in completing all his work so the company goals are achieved. $R S X$ is a private hospital, in preliminary observations several problems emerged, including teamwork that was not working well between employees, the lack of good communication between employees, the compensation provided was not appropriate and employee tardiness from attendance and employee turnover was quite high. The purpose of this study was to analyze the factors that influence employee motivation in the hospital. The method of this research was carried out by analytic causality survey with one short study time dimension. The population in this study was 293 people. The sample in this study used purposive sampling technique. The data analysis method used in this study is multiple linear regression analysis. Based on the results of the regression analysis, the regression coefficient value shows that the regression coefficient for teamwork has the highest value compared to the regression coefficient for work environment and compensation. This shows the good teamwork can increase employee motivation. The results showed based on the results of the analysis, the simultaneous effect of teamwork, work environment, and compensation on motivation had a positive effect in the hospital. teamwork, work environment, and compensation to motivation have a positive effect. The greatest coefficient value in this study is the variable teamwork at $52.6 \%$. Implications for Hospital Management to enhance team collaboration with team building training and conflict management training. To increase motivation and compensation satisfaction by improving a transparent performance appraisal system, adjusting workloads with compensation and defining a clear career path in the hospital environment.Based on this, solid teamwork, a conducive work environment and a good compensation system in the hospital, it is easy for the hospital to increase motivation and quality of service, so it can produce quality products with competitive service prices.

Keywords: Teamwork, Work Environment, Compensation, and Motivation.

\section{INTRODUCTION}

In the era of globalization marked by rapid changes, an organization or institution is required to make adjustments in all aspects of the organization. With the limited human resources available, the organization is expected to optimize it so it can achieve the organizational goals that have been set. Human resource management is part of organizational management focuses on the element of human resources [1].

Motivation is important to be in research because the company and human resources are two groups support each other and have a relationship with one another. Therefore, we need a mutually beneficial cooperation. In a company,
Submitted : February 12, 2021

Published : February 19, 2021

ISSN: 2507-1076

DOI: $10.24018 /$ ejbmr.2021.6.1.749

Anisah Sri Astuti *

Master of Hospital Administration Programme, Esa Unggul University, Jakarta, Indonesia.

(e-mail: anisah.sriastuti@yahoo.co.id) Hasyim

Master of Hospital Administration Programme, Esa Unggul University, Jakarta, Indonesia.

(e-mail: hasyim.ahmad@esaunggul.ac.id) Nofierni

Master of Hospital Administration Programme, Esa Unggul University, Jakarta, Indonesia.

(e-mail: nofi.erni@esaunggul.ac.id)

*Corresponding Author human resources are one of the resources that make a very dominant contribution or can even be said to play a very important role among other resources [2], [3].

The Integrated Health Hospital - Dompet Dhuafa (RST) has been accredited by KARS Paripurna in 2018 as a provider of health services for the people in Bogor Regency who are required to provide good and quality health services for the community. The importance of hospitals in maintaining the quality of services because the community's need for health services is very high. Therefore, one way for the hospital to achieve its goal of providing quality health services for the community is to pay attention to employee motivation to work. Employees who have high motivation will produce good performance, so it has a positive 
influence on hospital performance.

Motivation consists of two types, namely intrinsic / internal motivation, which is motivation comes from within yourself or each person and extrinsic / external motivation is motivation that does not come from yourself, such as colleagues and superiors. Motivation is an important thing for management to pay attention to if they want each employee to make a positive contribution to the achievement of company goals. With motivation, an employee will have high enthusiasm in carrying out the tasks assigned to him. Without motivation, an employee cannot fulfill his duties according to standards or even exceed the standard because his motivations for work are not fulfilled. Even if an employee has good operational skills if he is not motivated to work, the results of his work will not be satisfactory [4], [5].

In previous research conducted by Muchti Yuda Pratama entitled "The Influence of Intrinsic Motivation on the Performance of Implementing Nurses of Tk. IV in Pematang Siantar" gives the result that there is a significant influence of responsibility, opportunity to advance, and recognition on performance on the performance of nurse administrators, this can be seen from the results of linear regression tests. Compensation has also been shown to have a positive effect on motivation, such as a study researched by Yadi Maryadi entitled "The Effect of Compensation on Employee Motivation at Regional General Hospital in Besemah Kota Pagar Alam" shows the results of a significant effect.

The results of research conducted by Yenny $\mathrm{V}$. Handayani, Rokiah Kusumapradja [6] stated that "the variable of work motivation for nurses is the most dominant variable and has the most significant effect on the application of the patient safety program. The higher the work motivation of nurses, the higher the success of implementing the patient safety program"

The importance of employee motivation has also been researched by [7] entitled "Pay, Intrinsic Motivation, Extrinsic Motivation, Performance, and Creativity in the Workplace: Revisiting Long-Held Beliefs". The results showed that salary, intrinsic and extrinsic work motivation had a positive effect on the creativity of employee performance which could make the organization potentially able to compete with other organizations.

Many factors can affect employee motivation to work in a company, one is the work environment. The work environment is a very important component in employees completing their work. For this reason, companies must pay attention to the work environment so that employee performance can be even better. With the room neatly arranged, the painting of the walls in line with the brightness of the room, the office yard is clean, and the surrounding area is neat, the air in the room is always comfortable because the air circulation through the window vents will make employees comfortable at work, so employees can work better [5].

According to the results of the study [8] entitled "Exploration of the Meaning of a Healthy Work Environment for Nurses", it shows the psychological work environment has a more significant effect on work motivation, nurses say they need to feel valued and receive meaningful recognition. Based on these results, it means a good work environment can motivate employees to work.

In addition to the work environment, one thing that affects employee motivation is teamwork. Teamwork is considered the best solution for achieving success in an organization. The role of teamwork is to facilitate managers or employees in making decisions about what to do to achieve company goals. Teamwork is useful for maintaining the harmony of a team so the realization of a job satisfaction that can affect individual and organizational performance [1].

The importance of teamwork is also evidenced by the results of a study conducted by Kevin J. et al. [9] entitled "Team work Essentials for Hospitalists" which states the Hospital Management is an important challenge for Management. Measurement is key to understand baseline performance and assess whether teamwork is increasing or decreasing so regular evaluation is needed.

In another journal entitled "The Role of Teamwork in Improving Patient Safety Culture", it is stated that in hospital services the role of teamwork is very important in creating a culture of patient safety [10].

Another factor that can affect employee motivation to work in the hospital is a compensation. Compensation is something that employees receive in exchange for their service contributions to the organization. If managed properly, compensation helps the organization achieve its goals and acquire, maintain and look after employees properly [11].

Compensation has two aspects. First, direct financial payments in the form of wages, salaries, incentives, commissions, and bonuses; and second, indirect payments in the form of financial benefits, such as insurance and company paid vacation fees [12].

The results of research conducted by Widuri, Maryadi, Yuli Vianasih [5] entitled "The Relationship of Reward Giving with Nurses' Work Motivation in the Inpatient Room at JIH Hospital Yogyakarta" which showed there was a significant relationship between reward giving and the work motivation of nurses in the room. JIH Hospital Yogyakarta 2015 (p 0.047) with a very strong relationship closeness ( $\mathrm{r}$ 0.831). Apart from teamwork and the work environment, compensation is also one of the factors that affect employee motivation in the company [13].

Another finding in a research journal conducted by Soekardi, A., Indrawati, R. and Erni, N. [14] entitled "The influence of communication skills toward employee performance in radiology installation unit of hospital", is that effective communication is the most influential factor in staff performance. From this effective communication creates a good relationship between leaders and staff. In this communication there is satisfaction and motivation, therefore employee performance will increase, this shows the direction of a positive relationship between communication and performance, which means that the more effective communication, the employee performance will increase, this is related to Abraham. Maslow's hierarchy of needs theory. The results of this study are related to the research that the researchers studied, namely teamwork and a psychological work environment including good communication between superiors and subordinates, and coworkers. 
The researcher conducted a preliminary study from the results of the survey, the researcher concluded the psychological work environment which includes the work relationship formed in the institution between superiors and subordinates is not going well. Compensation at the hospital is not in accordance with work, and the hospital has not provided employees with opportunities for promotion. Pressure from the head of the room makes subordinates or executors feel uncomfortable so that a conducive work environment is not created. Employees think that the hospital does not motivate employees to work because it does not reward employees with good performance, which causes employees to be demotivated towards their work. Compensation received by employees is not satisfactory and employees consider it not in accordance with the workload done. In the category of teamwork, there is still a gap both among medical personnel and in the communication of medical and non-medical personnel which results in errors that are detrimental to patients and to the hospital.

\section{METHOD}

This study uses a survey method with an associative quantitative questionnaire and causality aims to determine the effect of variables by analyzing related factors. The population in this study was 293 people. The sample in this study used purposive sampling technique. Researchers determine sampling by determining specific characteristics in accordance with the research objectives, employees who work> 6 months, the sample size in the study that fits the criteria is as many as 220 people. Data analysis using multiple linear regression was carried out to predict the form of the relationship, determine the direction and magnitude of the influence between the independent variables and the dependent variable. This research has received information that has passed the ethical review of the Esa Unggul University Research Ethics Commission in an effort to protect the human rights and welfare of the subject, no. 0324-20.304 / DPKE-KEP / FINAL-EA / UEU / IX / 2020.

\section{A. Variable Measurement}

This research was conducted to explain the relationship of three variables, the independent variable which includes teamwork (X1), work environment (X2), and compensation (X3) with the dependent variable, motivation (Y), so the type of research used is associative quantitative, because the researcher wants to know whether there is a relationship between the variables through testing the hypothesis that has been formulated.

The motivation variable has dimensions [4]:

1. Intrinsic.

2. Extrinsic

The Teamwork Variable has dimensions [15]:

1. Commitment to the Common Goals of Teamwork.

2. Team Decision Making.

3. Team Conflict Handling.

Work Environment Variables have dimensions [16]:

1. Physical Work Environment Factors.

2. Psychological Environmental Factors.

The Compensation Variable has dimensions [12]:

1. Wages.

\section{Facilities or Benefits.}

3. Promotion.

The measurement scale in this study uses Likert scale 1 5 with 1 (Strongly Disagree) up to 5 (Strongly Agree).

The relationship between the research variables is described in the following constellation:

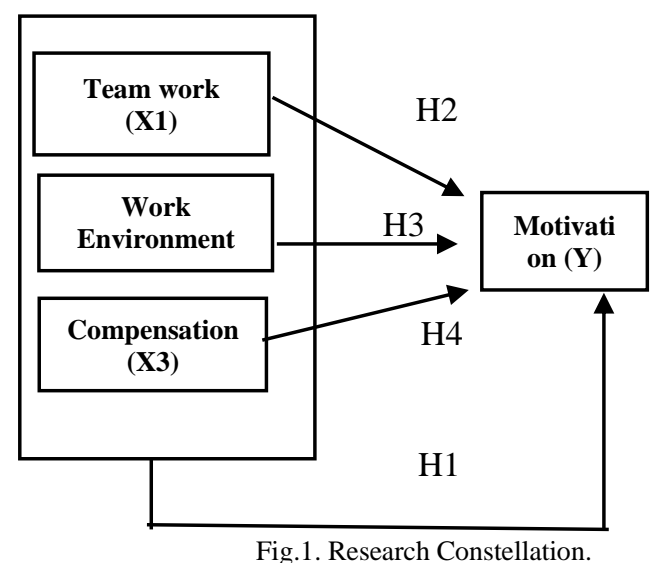

\section{B. Research Hypothesis}

Based on the research constellation, the research hypothesis is as follows :

H1: Teamwork, Work Environment, and Compensation affect Work Motivation.

$\mathrm{H} 2$ : Teamwork affects employee motivation.

H3: Work environment affects employee motivation.

$\mathrm{H} 4$ : Compensation for employee motivation.

\section{RESULT}

A. Description of Respondents' Data TABLE 1: DisTRIBUTION OF RESPONDENT CHARACTERISTICS

\begin{tabular}{ccc}
\hline Age Category & $\mathrm{N}$ & Percentage \\
\hline Aged 20-35 & 121 & $55 \%$ \\
Aged 35-50 & 99 & $45 \%$ \\
Total & 220 & $100 \%$ \\
Gender Category & $\mathrm{N}$ & Percentage \\
Male & 53 & 24 \\
Female & 167 & 76 \\
Total & 220 & 100 \\
Work Category & $\mathrm{N}$ & Percentage \\
Medical personnel & 171 & 78 \\
Non Medical & 49 & 22 \\
Total & 220 & 100 \\
Work Period & $\mathrm{N}$ & Percentage \\
1-5 Years & 99 & 45 \\
> 5 Years & 121 & 55 \\
Total & 220 & 100 \\
Education & $\mathrm{N}$ & Percentage \\
DII & 52 & 24 \\
S1 & 145 & 66 \\
S2 & 23 & 10 \\
Total & 220 & 100 \\
\hline
\end{tabular}

Based on the data above, it is known 220 respondents who were studied based on gender, it was found that female gender was a larger proportion than male employees. Most of the employees are in the age group of 20-30 years (54.64\%). 220 respondents studied based on education, the education level was dominated by S1, amounting to $65.98 \%$. Furthermore, respondents studied based on tenure, amounted to $45.36 \%$ of respondents have worked for $1-5$ 
years and a period of service> 5 years $54.64 \%$. The type of work of the most respondents was the Medical Personnel group $78 \%$.

\section{B. Description of Respondents' Responses}

Descriptions of respondents' answers are obtained from the total frequency of respondents in providing answers in each statement that measures the research variable. The results of the descriptive analysis recapitulation are presented as follows:

TABLE 2: RESPONDENTS' RESPONSES

\begin{tabular}{|c|c|c|c|c|}
\hline \multirow[t]{2}{*}{ No } & \multirow[t]{2}{*}{ Variable } & \multicolumn{2}{|c|}{$\begin{array}{c}\text { Respondent } \\
\text { Response Position }\end{array}$} & \multirow[t]{2}{*}{ Information } \\
\hline & & Index & Category & \\
\hline 1 & Motivation & 166 & High & $\begin{array}{l}\text { Employees are always } \\
\text { passionate about work }\end{array}$ \\
\hline 2 & Teamwork & 165 & High & $\begin{array}{l}\text { Employees can work } \\
\text { together as a team well }\end{array}$ \\
\hline 3 & $\begin{array}{c}\text { Work } \\
\text { environment }\end{array}$ & 164 & High & $\begin{array}{c}\text { Employees stated that } \\
\text { the work atmosphere } \\
\text { both physically and } \\
\text { psychologically was } \\
\text { good enough }\end{array}$ \\
\hline 4 & Compensation & 168 & High & $\begin{array}{l}\text { Financial and non- } \\
\text { financial compensation } \\
\text { is considered } \\
\text { satisfactory }\end{array}$ \\
\hline
\end{tabular}

From Table 2 above, the respondent's responses to the variables of motivation, teamwork, work environment, and compensation are obtained.

\section{Hypothesis}

The method used to analyze the data in this study is the multiple regression method between the independent variable and the dependent variable with the following equation:

\begin{tabular}{cc}
\multicolumn{2}{c}{ TABLE 3: REGRESSION EQUATIONS } \\
\hline Model & B \\
\hline (Constant) & 7.591 \\
Teamwork & .475 \\
Work environment & .094 \\
Compensation & .249 \\
\hline
\end{tabular}

The regression equation in this study is as follows:

$$
\mathrm{Y}=\mathrm{a}+\mathrm{b} 1 \mathrm{X} 1+\mathrm{b} 2 \mathrm{X} 2+\mathrm{b} 3 \mathrm{X} 3+\mathrm{e}
$$

$$
\begin{gathered}
\mathrm{Y}=7.591+0.475 \text { Teamwork }+0.094 \text { Work Environment } \\
+0.249 \text { Compensation }
\end{gathered}
$$

The $\mathrm{F}$ test is performed to test the hypothesis and determine the effect of the independent variables simultaneously on the dependent variable. The results of the F test get the calculated $F$ value of 36,462 and at the sig. $<0.05$ means that the regression coefficient is significant. This can be interpreted, if Teamwork, Work Environment, Compensation increases simultaneously, the motivation of employees in the hospital will also increase. The t test was conducted to determine the effect of the variable partially on the independent variable. The t test results can be seen in the following table:
TABLE 4: REGRESSION COEFFICIENT AND T TEST

\begin{tabular}{ccccc}
\multicolumn{4}{c}{ TABLE 4: REGRESSION COEFFICIENT AND T TEST } \\
\hline Variable & $\mathrm{t}$ & $\mathrm{Sig}$ & $\mathrm{B}$ & Information \\
\hline $\mathrm{X} 1$ & 9.141 & .000 & .724 & $\mathrm{H} 2$ accepted \\
$\mathrm{X} 2$ & 5.738 & .000 & .275 & $\mathrm{H} 3$ accepted \\
$\mathrm{X} 3$ & 7.976 & .000 & .511 & $\mathrm{H} 4$ accepted \\
Variable & $\mathrm{f}$ & $\mathrm{Sig}$ & & Ket \\
$\mathrm{X} 1-\mathrm{X} 3$ & 36,462 & .000 & $\mathrm{H} 1$ accepted \\
& \multicolumn{4}{c}{ Regression Coefficient } \\
R & \multicolumn{3}{c}{ R Square } \\
.923 & & & .841 \\
\hline
\end{tabular}

Based on the table of the Sighcount value of $0.000<0.05$, meaning the regression coefficient is significant, then Ho is rejected, or Ha is accepted, so it can be concluded there is a significant influence between Teamwork, Work Environment and Compensation, partially influencing motivation.

The coefficient of determination test results showed the $\mathrm{R} 2$ value was 0.841 or $84.1 \%$. Based on the table, it can be seen the motivation is influenced by Teamwork, Work Environment, and Compensation of $84.1 \%$ while the rest is influenced by other factors outside the variables tested in this study.

\section{DISCUSSION RESPONDENT CHARACTERISTICS}

220 respondents who were studied based on gender; it was found that female gender was a greater proportion than male employees. Most of the employees are in the age group of 20-35 years $(54.64 \%)$. Workers of productive age tend to experience higher selfish psychological conditions when compared to older workers. This can happen because younger workers tend to want to excel when compared to older workers, this can affect teamwork within the organization.

H1: The Effect of Teamwork, Work Environment, and Compensation on Motivation

Based on the results of testing the first hypothesis, it is successful to prove that there is a positive and significant influence between teamwork, work environment, and compensation simultaneously on employee motivation at Rumah Sehat Terpadu Hospital - Dompet Dhuafa (RST). where is the sig. 0.000 is less than 0.05 . This can be interpreted that if Teamwork, Work Environment, and Compensation simultaneously increase, the motivation of employees at the Integrated Health Hospital - Dompet Dhuafa (RST) will also increase.

The value of R. square has the greatest influence, namely the variable of teamwork by $52.6 \%$, and the variable of compensation of $47.5 \%$, and the last which has the least influence is the variable of work environment by $36.2 \%$.

From the research results, it was found that the effect of teamwork was $52.6 \%$, this shows that employees are aware of working in a team to carry out tasks together, are responsible for work quality, have a strong share of team success, have a high contribution in achieving goals, members the team is aware of their respective roles to achieve the targeted goals, leaders who really care about members and provide ideas for the progress of the team. Thus, the higher the teamwork, the higher the motivation generated by the employees.

Human resources are one of the most valuable assets owned by a company. This human resource element is one 
of the key factors that a company must maintain in line with the demands that the company constantly faces to answer any existing challenges. This is in accordance with the opinion of Gomes [17] "Human resources are resources that have reason, feelings, desires, abilities, skills, knowledge, drive power". For companies, efforts to increase employee motivation and maintain quality human resources are very important.

\section{H2: The Effect of Teamwork on Motivation}

The mean value of the questionnaire value for the teamwork variable is 165 and is included in the High category. This means that according to respondents the teamwork at the hospital is good enough for employees so that employee motivation towards the hospital is high. The highest index is found in the indicator of decision making in the team based on truth, even though it can trigger conflict with an index value of 174. This shows that in hospitals decision making is based on the principle of justice and is based on truth, even though it can lead to conflict.

Indicators that fall into the MEDIUM category are my place, employees work in teams and where I work, the team gives mutual appreciation for the achievement of the common goals of 220 respondents who answered disagree with $60 \%$ of the total respondents, this shows that the respondent stated:

1. Lack of trust between team members.

2. Fear of conflict.

3. Lack of commitment in the team.

4. Avoiding accountability.

5. Indifference to the team's results.

The results of linear regression analysis show that the variable teamwork has a significant effect on employee motivation at Rumah Sehat Terpadu Hospital - Dompet Dhuafa (RST). Partially Teamwork also affects employee motivation. This can be seen from the significant results of the $\mathrm{t}$ test of 0.000 or less than 0.05 so that the second hypothesis is accepted. This shows that if employee teamwork is getting better it is expected that employee motivation will increase.

Collaboration is the mental and emotional involvement of people in group situations that encourages them to contribute to group goals or share responsibility for achieving goals. A work team generates positive synergy through coordinated efforts that will result in better performance than the performance of individuals in an organization. Good teamwork is significantly related to employee work motivation, where if teamwork is maximized it will provide maximum work efficiency and achieve organizational goals.

\section{H3: The Effect of Work Environment on Motivation}

The average value for the Work Environment variable is 164 and is in the High category. This means that according to respondents the hospital work environment is quite conducive and comfortable, and the hospital provides the best for employees so that employee motivation towards the hospital is high. The highest index is found in the indicator of the physical work environment, namely the availability of clean toilets that can increase comfort in working with an index value of 174. This shows that employees are quite comfortable with the physical environment provided by the hospital.
Indicators that fall into the MEDIUM category are:

1. At my place the cleaning service is working well.

2. Security officers are there 24 hours.

3. In my work environment good communication between colleagues has been created.

4. At work I have established good communication with my boss to motivate work morale.

Of the 220 respondents who answered disagree with $60 \%$ of the total respondents, this indicates that the respondent stated that the work environment is one of the closest things to a person in carrying out his work. The work environment around employees needs to be considered in order to have a good impact on one's performance. A sense of comfort and safety will be created because of an adequate work environment. From the physical work environment factor, cleaning services in hospitals, cleaning services do not carry out their duties properly, and security officers are still not maximal in their duties.

The results of the linear regression analysis show that the work environment variable has a significant effect on employee motivation at Rumah Sehat Terpadu Hospital Dompet Dhuafa (RST). Partially the work environment also affects employee motivation. This can be seen from the significant results of the $t$ test of 0.000 or less than 0.05 so that the third hypothesis is accepted. This shows that if the employee's work environment is better improved, employee motivation will increase. Employees who have a Good Work Environment automatically have good motivation for the company.

The results of the study according to Johansen et al. [8] entitled "Exploration of the Meaning of a Healthy Work Environment for Nurses" show that the psychological work environment is very influential on the motivation of nurses to carry out Nursing Care. Nurses state that they need to feel appreciated and receive meaningful recognition. The work environment can be interpreted as the whole tooling tool faced, the surrounding environment where a person works, his work method, as an influence of his work both as an individual and as a group.

\section{H4: Effect of Compensation on Motivation}

The average value for the Compensation variable is 168 and is included in the High category. This means that according to the respondents the organization has provided the best compensation for employees so that employee motivation to the hospital is high. The highest index is found in the compensation indicator. Career paths are carried out transparently with an index value of 180 . This shows that the hospital has provided the best compensation system for employees.

Indicators that fall into the medium category, namely allowances provided by the hospital are in accordance with the regulations of 220 respondents who answered disagree with $60 \%$ of the total respondents, this shows that the respondent stated: the benefits received were not in accordance with the regulations. In relation to the reinforcement theory, compensation payments based on skills will encourage employees to learn continuously, develop their skills, and be able to work together with other members of the company. The more developed the skills he has, the greater the compensation he will receive. 
The results of linear regression analysis indicate that the compensation variable has a significant effect on employee motivation at Rumah Sehat Terpadu Hospital - Dompet Dhuafa (RST). Compensation partially also affects employee motivation. This can be seen from the significant results of the t test of 0.000 or less than 0.05 so that the fourth hypothesis is accepted. This shows that if employee compensation is further improved, employee motivation will increase. Employees who have a Good Compensation system automatically have good motivation for the company.

According to Robbins [18], skill-based compensation is in accordance with Alderfer's ERG (Existence, Relatedness and Growth theory) theory, because this payment system can encourage employees to learn, improve their skills and maintain their skills. This can be interpreted that for employees who want to meet their needs better, the provision of compensation based on skills will be an impetus for them to further improve their skills, in order to obtain higher compensation, so that their needs can be met.

Compensation is important for employees because the amount of compensation reflects a measure of the value of their work among the employees themselves, their families and the community. Compensation programs are also important for organizations to retain employees or so that employees have high loyalty and commitment to the organization.

It is known the average value for the Compensation variable is 168 and is included in the High category. This means according to the respondents the organization has provided the best compensation for employees so employee motivation to the hospital is high. The highest index is found in the compensation indicator. Career paths are carried out transparently with an index value of 180 . This shows the hospital has provided the best compensation system for employees.

It is known the average score for the Motivation variable is 166 and it is in the High category. This means that employee motivation is high enough. The highest index is found in the Motivation indicator, employees are always enthusiastic in working with an index value of 173 . This shows employees are always excited about the work given by the hospital.

\section{RESEARCH FINDING}

The difference between this study and other studies is that in this study teamwork affects motivation more. And extrinsic motivation has a greater influence where other studies of intrinsic motivation dominate. Based on this, the researcher found that the effectiveness of using intrinsic and extrinsic motivation sources could be different when viewed from other aspects because researchers conducted research at RST Dompet Dhuafa Hospital which was oriented towards Charity in accordance with the Hospital Vision, namely "To be the main choice hospital that provides health services in a professional and Islamic nuances for the community, especially the poor".

\section{CONCLUSIONS, IMPLiCATIONS AND SUGGESTIONS}

\section{A. Conclusions}

The results of the effect test either partially or jointly between Teamwork, Work Environment, and Compensation have a positive and significant effect on Employee Motivation. This means with solid teamwork, a conducive work environment and a good compensation system at the hospital, the hospital can easily increase employee motivation and service quality, so it can produce quality products with competitive service prices.

\section{B. Managerial Implications}

Based on the research results that have been obtained, the efforts that can be made by the management and leaders of the hospital are as follows :

\section{Team work}

Create Conflict Management Training for all employees. This conflict management training is designed to help employees and leaders to think and act positively, and intelligently manage each conflict to become a force that unites the organization and its stakeholders in a single vision directed towards the right goals.

\section{Work Environment}

Hospital management can create a conducive and comfortable work environment for employees so that employee motivation can increase

\section{Compensation}

In hospitals, management can offer other forms of compensation, namely the opportunity to continue their education, attend training according to competence, or spiritual tourism trips for high-achieving employees, such as the Umrah or Haj pilgrimage.

\section{Motivation}

One way to motivate employees is by implementing a reward and punishment system. Reward is one of the important control tools used by the company to motivate personnel to achieve company goals with the behavior expected by the company.

\section{Suggestion}

From the results of the analysis and conclusions, the researchers try to make some suggestions :

1. Regarding Collaboration The research team advises the leadership to hold meetings and evaluations more often because they are faced with various types of characters and different traits, the first step is to build trust in the team, overcome fear of conflict, grow commitment in the team, carry out accountability in the team, focus attention on the results the team needs to achieve

2. In the Work Environment variable, Leaders are expected to complete the facilities and infrastructure at the Hospital, add cleaning officers in the Hospital environment so that hospital cleanliness can be maintained, increase the number of security officers in the Hospital area, make routine daily, weekly or monthly meeting agendas between Management is related to employees so that a conducive atmosphere is created. Management can hold employee gathering events to build emotional closeness and psychological attachment between employees and superiors so that communication can be established in a conducive way. 
3. In the hospital, management can offer other forms of compensation, the opportunity to continue their education, attend training according to competence, or travel the Umrah or Haj pilgrimage for high-achieving employees.

4. Leaders are expected to be able to create situations and conditions that allow each employee to excel and perform better. This is done by holding managerial meetings to discuss rewards and punishments as well as adjustments to the workload for compensation

5. Hospitals can strive to provide a reward system according to individual employee achievements, improve thinking processes in the form of training and skills development for those who excel, so employees feel motivated to have achievements at work.

\section{GRATITUDE}

The author would like to thank Dr. Hasyim, SE, MM, M. Ed. and Dr. Nofierni, MM as the supervisor. As well as Dr. Rokiah Kusumapradja SKM, MHA as the examiner of the results of this research.

\section{REFERENCES}

[1] Sisvana Damayanti, (2018). Faktor-Faktor yang Berhubungan dengan Motivasi Kerja Pegawai Tetap di Rumah Sakit Umum Daerah Kabupaten Penajam Paser Utara Kalimantan Timur Tahun 2018. Departemen Administrasi dan Kebijakan Kesehatan Fakultas Kesehatan Masyarakat Universitas Indonesia Jurnal ARSI/Februari 2018.

[2] A.H. Maslow, Frederick Herzberg, dan David McClelland. 2005. Job Satisfaction Theory.

[3] Muchti Yuda Pratama, (2017). Pengaruh Motivasi Intrinsik Terhadap Kinerja Perawat Pelaksana Di Rumah Sakit Tk. Iv Pematang Siantar. Dosen Akper Kesdam I/Bukit Barisan Medan, Jalan Putri Hijau No. 17 Medan.

[4] Herzberg. (1966). Work and The Nature of Man. New York: Work Publishing Co.

[5] Widuri, Maryadi, Yuli Vianasih, (2019). Hubungan Pemberian Reward Dengan Motivasi Kerja Perawat Di Ruang Rawat Inap Rumah Sakit Jih Yogyakarta. Program Studi S2 Ilmu Keperawatan STIKES Guna Bangsa Yogyakarta.

[6] Yenny Handayani, Kusumapradja Rokiah, (2018) Pengaruh Motivasi Kerja Perawat Terhadap Penerapan Program Keselamatan Pasien Di Unit Rawat Inap Rumah Sakit X Tangerang Selatan. Hospitalia, Volume 1 Nomor 1, Februari 2018.

[7] Barry, Gerhart, and Meiyu Fang, (2017). Pay, Intrinsic Motivation, Extrinsic Motivation, Performance, and Creativity in the Workplace: Revisiting Long-Held Beliefs. First published online as a Review in Advance on January 12, 2017. This article's doi: 10.1146/annurevorgpsych-032414-111418.

[8] Mary L. Johansen, PhD, RN, NE-BC, FAAN, Pamela B. de Cordova, $\mathrm{PhD}, \mathrm{RN}-\mathrm{BC}$, and Susan H. Weaver, PhD, RN, CRNI, NEA-BC (2020). Exploration of the Meaning of Healthy Work Environment for Nurses.

[9] Kevin J. O’Leary, MD, MSa, Krystal Hanrahan, MS, MSPH, RN, CMSRNb, Rachel M. Cyrus, MD (2020). Team work Essentials for Hospitalists.

[10] Febriansyah, Kusumapraja Rokiah, Ahmad Hasyim, 2020 The Role of Teamwork in Improving Patient Safety Culture, JMMR (Jurnal Medicoeticolegal dan Manajemen Rumah Sakit), 9 (1): 41-52, April 2020.

[11] Nuning Gustian, Muzakkir, Hasmin Tamsah, (2017). Pengaruh Gaya Kepemimpinan Kepala Ruangan, Manajemen Waktu, Dan Kompensasi Terhadap Motivasi Kerja Perawat Di Rsud Haji. Jurnal Mirai Management Volume 2 No. 2 April - Januari 2017.

[12] Dessler, Gerry, 1997. Human Resource and Personel Management, McGawa- Hill Book, CO, Singapore.

[13] Gibson, Ivanceivich, Donnelly, Konopeske, Organizational Behavior, Thirteenth Edition, Singapore: McGraw Education, 2009.

[14] Soekardi, A., Indrawati, R. and Erni, N. (2020), "The influence of communication skill toward employee performance in radiology installation unit of hospital", Management and entrepreneurship: trends of development, Volume 4, Issue 14, pp. 31-42.

[15] Thompson, L. 2000. Making the team. A guide for managers. New Jersey: Pretice-Hall Inc.

[16] Davis, Keith, \& Newstrom, W., John. 1996. Human Behavior at Work: Organizational Behavior. New York: McGraw Hill International.

[17] Gomes (2008) Manajemen Sumber Daya Manusia. Jakarta: Andi Yogyakarta

[18] Robbins (2001), Perilaku Organisasi. Jakarta: Salemba Empat.

[19] Maryadi. (2011). Sistem Perencanaan dan Pengendalian Manajemen. Jakarta: Salemba Empat. 